\title{
A BIBLIOGRAPHICAL MYTH
}

About a year ago the writer's attention was called by Professor Kittredge to a paper in Transactions of the Edinburgh Bibliographical Society, entitled "The First Book Printed by James Ballantyne: Being An Apology for Tales of Terror; with Notes on Tales of Wonder and Tales of Terror." This valuable article, written almost thirty years ago, from material newly come to light, seems to have remained largely unknown. Information regarding the Apology for Tales of Terror has, of late years, been creeping into the textbooks; but the "Notes," which are based on a collation of the original editions of all the books, ${ }^{1}$ and which show clearly that "Monk" Lewis was not the author of Tales of Terror, have had no effect on the Lewis legend, which continues to be restated without variation in books dealing with the subject, down to the present time. The recent appearance, therefore, of a new book on the Tale of Terror, seems to furnish a fitting opportunity to lay the ghost of this ancient error, which has haunted the bibliographies for nearly a century, and now turns up again in the latest contribution to the literature of the subject. ${ }^{2}$

The only collection of tales in verse ever published by "Lewis the Monk-man" was his "hobgoblin repast," Tales of Wonder, the far-famed miscellany of ghost and witch ballads, for which he solicited "marvellous" contributions from all quarters, and to which Walter Scott, the young Edinburgh advocate, was proud to contribute five pieces. He was at that time so entirely unknown to the London literary world that Lewis prefaced "The Fire-King," the first in order of his poems, by the statement that the author was the translator of Goethe's Götz von Berlichingen, and called attention to the other ballads in the book by "this gentleman." Two editions of

\footnotetext{
1 All of these books, including a copy of the exceedingly rare Apology for Tales of Terror, were already in the Harvard Library, with one exception, the second edition (1808) of Tales of Terror, which was later secured. Since then, they have been collated independently, with the results shown in the following pages.
}

2 Birkhead, Edith, The Tale of Terror. A Study of the Gothic Romance. (London, 1921.)

[Modern Philology, February, 1922] 
Tales of Wonder were published in London during the year 1801. Between these two editions, some unknown person published Tales of Terror anonymously.

The similarity in titles, the fact that the second edition of Tales of Wonder was a single volume, uniform in size with Tales of Terror, and the advertisement of the publisher that one would make a good second volume for the other, all helped to obscure the facts, and in 1834 Lowndes, in his Bibliographers' Manual, listed Tales of Terror along with Tales of Wonder among Lewis' works. ${ }^{1}$ Others followed suit, and the final seal of authority was set on the misstatement when Professor Morley, in 1887, published as Number 45 of his "Universal Library," the apocryphal Tales of Terror and Wonder, collected by Matthew Gregory Lewis. Since then no one seems to have questioned the matter; Lewis has been everywhere accepted as the undoubted author of Tales of Terror, and the error so stands in the Dictionary of National Biography, the Cambridge History of English Literature, and the works of a large number of eminent scholars.

It is unfortunate that Professor Morley did not seem to consider accuracy as of much importance in reprinting these old editions. He doubtless believed Lewis to be the author, or compiler, of both works, and he did good service in making the text more accessible; but his Introduction is worse than useless as a contribution to scholarship, because it is directly misleading as to the main facts. Lewis, he says,

had written, after the wild German fashion, some of the ballads afterwards included in his Tales of Terror and Tales of Wonder; . . . . Scott had been translating from the German, Bürger's "Lenore" and "The Wild Huntsman"; had written "The Eve of St. Agnes," and he opened his heart and his store to so congenial a friend. Lewis published at Kelso, in 1799, his Tales of Terror, followed them up in the next year with his Tales of Wonder, and produced afterwards Tales of Wonder in London in 1801, in 2 vols., royal 8vo, with additional pieces collected from various sources. In this volume the original books are reprinted, except that four leaves missing in the Tales of Terror compelled the omission of one tale, because another copy of the book could

1 See footnote 3, page 310 .

Watt, in his Bibliotheca Britannica (1824), lists the anonymous Tales of Terror correctly under "Terror" in the subject catalogue; but he also inserts under Lewis" name, between works of 1806 and 1808, "Tales of Terror, 3 vols." (undated). This may be the source of the "Tales of Terror. 2 vols. 1807" listed in the Life and Correspondence of Lewis, published in 1839 . Nothing whatever is known of such a work, in either verse or prose. 
not be found. It is not in the British Museum, and the London Library contains only the 1801 edition of the Tales of Wonder. It is in these little books that Scott made his first appearance as a poet.

"Eve of St. Agnes" is here, of course, a mere slip for "Eve of St. John," but the other statements cannot be disposed of so easily. Lewis did not publish Tales of Terror at Kelso in 1799. So far as is known, he never published any Tales of Terror at all, in either prose or verse, and the only work that can be found with that title is the anonymous Tales of Terror, already mentioned. Nor did he in the "next year," 1800, publish Tales of Wonder. His two octavo volumes of Tales of Wonder, published in London in 1801, were the first edition of that work, and so could not contain "additional pieces." Moreover, there is nothing by Scott in Tales of Terror, and he did not "make his first appearance as a poet" in Tales of Wonder; for if that phrase does not apply, strictly speaking, to his anonymous publication in 1796 of his "William and Helen" and "The Chase," the two translations from Bürger that Morley mentions, he surely did make his appearance as a poet when he published under his own name in 1800 his original ballad, "The Eve of St. John."

Furthermore, Professor Morley's statement that he reprinted from "the original books," coupled with his account of these books, would mean, on the face of it, that he reprinted (1) from Tales of Terror published by Lewis at Kelso in 1799, a wholly mythical source; and (2) from a hypothetical first edition in 1800 of Lewis' Tales of Wonder, which was in reality the second edition of that work, and says so, in capital letters, on the title-page.

As a matter of fact, a comparison of Tales of Terror and Wonder with the first and second editions of each of the original books, makes it clear that Morley printed the first part of his publication from the first edition of the anonymous Tales of Terror, and the second part from the second edition of Lewis' Tales of Wonder, which contained thirty-two of the sixty pieces in the first edition. All three of the books in question, the first edition of Tales of Terror and the first and second editions of Tales of Wonder, are London publications of the year 1801 .

But there was a book printed (though not published) at Kelso in 1799 that has to do with both Lewis and Scott in a very curious way. This is the Apology for Tales of Terror, of which twelve copies were 
printed at Scott's request, for private circulation, by his old school friend, James Ballantyne, who was at that time editor of a weekly newspaper, the Kelso Mail. Scott had suggested that Ballantyne try to get some book-printing to do, to keep his types, which were excellent, in play during the rest of the week; and finding him pleased at the idea, had caused him to strike off the dozen copies for his Edinburgh acquaintances, that they might judge for themselves of Ballantyne's skill. But the ballads printed in the Apology for Tales of Terror were not, as Lockhart has stated," ${ }^{1}$ Scott's "recent pieces, designed to appear in Lewis' collection" (Tales of Wonder). Only three of them were by Scott, and these were his two translations from Bürger, already published, and his "Erl-King," translated from Goethe two years previously, and not designed to appear in Tales of $W$ onder, presumably because Lewis preferred his own version of that ballad.

The Apology for Tales of Terror has, of course, nothing whatever to do with the anonymous Tales of Terror, which was not yet in existence. Its title is explained by Scott's statement that Lewis' collection was "first intended to bear the title Tales of Terror, and afterwards published under that of Tales of Wonder" ;2 and "apology" refers to the long delay in bringing out this work, which Scott was eagerly awaiting. The curious thing is that Scott's connection with the A pology became entirely forgotten. The twelve copies dropped out of sight and remembrance, and the work itself, cited under the abbreviated title of Tales of Terror, was confused with the anonymous Tales of Terror, and then ascribed to Lewis, who had no hand in either book. ${ }^{3}$ Yet, for almost a hundred years Tales of Terror has passed current in the records of booksellers and bibliographers as one of his undoubted works; as a companion volume, in fact, to his Tales of Wonder, the second edition of which, as it happened, had been issued in one volume, at almost the same time, by the same printer and publisher, and in uniform small octavo size-but with

1 Pollard's edition of Lockhart's Life of Scott, I, 275.

2 In Essay on Imitations of the Ancient Ballad.

'Lowndes's entry under Lewis' name (Bibliographer's Manual, 1834) reads: “Tales of Terror. Kelso, 1799, 4to. First edition. . . . London, 1801, 8vo." Then follows "Tales of Wonder, London, 1801. roy. 8vo." This confusion of books and editions is, of course, what Morley followed in his Introduction, instead of the printed title-pages. 
the important difference that Lewis' name appears on the title-page of Tales of Wonder but not of Tales of Terror.

It was not until a copy of the forgotten Apology for Tales of Terror turned up at a book sale in 1893 that the matter was cleared up. This fell into the hands of a Scottish scholar, Mr. George P. Johnston, a member of the Edinburgh Bibliographical Society, who collated the various books and at the 1893-94 session of the Society presented the facts in the paper already referred to. The newly discovered Apology proved to be John Ballantyne's own copy, with his bookplate in it. It had also an inscription in James Ballantyne's handwriting, presenting it in 1807 to Murray, the publisher, from James Ballantyne and Co., as "the only copy in their possession." Murray apparently gave the book to the poet Campbell, for it also contained his bookplate. Campbell's library was bequeathed to his niece, wife of the Rev. W. A. Hill, Vicar of Maidenhead; and it was at the sale of his books in 1893 that the Apology came to light.

This exceedingly rare book, the Abbotsford copy of which was for a long time the only one known to be in existence, is a beautiful 76-page quarto, printed in large, clear type on heavy paper. Besides Scott's "Erl-King," "The Chase," and "William and Helen"; it contains Lewis' "Erl-King's Daughter," "Water-King," and "Alonzo the Brave and the Fair Imogine" (reprinted from The Monk); Dr. John Aikin's "Arthur and Matilda"; and Southey's "Lord William" and "Poor Mary, the Maid of the Inn," this last being the only one in the book to which the author's name is attached. ${ }^{2}$

Lockhart is again in error in including Scott's "Fire-King" here, ${ }^{3}$ but Lockhart had never seen or, at any rate, had never examined the A pology, as is evident from his misinterpretation of the letter written by Scott to Ballantyne in April, 1800. Scott, he says,

1 Mr. Johnston is in error in stating that the "Erl-King" in the Apology is Lewis"; unless, as might conceivably be the case, the text of the twelve copies varies. He discovered, after he wrote his first paper, that the copy of the Apology belonging to Professor Dowden had a different title-page. It was set for octavo size and had James Ballantyne's name on it as printer.

${ }^{2}$ It is not necessary to suppose, with Mr. Johnston, that Scott "forgot" the A pology when he later referred to his Minstrelsy of the Scottish Border as " the first work printed by my friend and school-fellow, Mr. James Ballantyne." This was, quite literally, the flrst "work" printed by Ballantyne, the A pology for Tales of Terror being merely a samplo of book-printing, and not a "work" in the ordinary sense at all.

${ }^{3}$ Life of Scott, I, 275. 
alluded in this letter to an intention which he had entertained, in consequence of the delay of Lewis' collection, of publishing "an edition of the ballads contained in his own little volume, entitled 'Apology for Tales of Terror.'" What Scott really said in that letter is this:

. . . . Some things have occurred which induce me to postpone my intention of publishing my ballads, particularly a letter from a friend, assuring me that the Tales of Wonder are actually in the printer's hand. In this situation I endeavour to strengthen my small stock of patience, which has been nearly exhausted by the delay of this work, to which (though for that reason alone) I almost regret having promised assistance. ${ }^{1}$

There can be no question that Scott is referring here not to his ballads in the Apology but to those that were to appear in Tales of Wonder. There was only one in the Apology that he had not already published, and this ballad, the "Erl-King," does not seem to have been published during his lifetime. It is quite likely, in view of his too generous admiration for Lewis' work, that he considered his own version of that ballad to be entirely eclipsed by Lewis'.

Of the nine pieces which had been printed in the Apology, five were afterward published in Tales of Wonder. These are Lewis' three poems, Scott's "The Chase" (under the title of "The Wild Huntsman," ") and Southey's "Lord William." Doubtless both of Scott's other pieces would have been included in the collection, along with his new ballads, if they had been the only translations available; but Lewis preferred his own version of the "Erl-King," and William Taylor's "Lenora," which keeps Bürger's original title.

As to the authorship of the anonymous Tales of Terror, it would seem as if even the most cursory examination must have dispelled the illusion that it was the work of Lewis. That the twenty poems in the first edition (the second has twenty-one) are from the hand of a single author is established by his note to the last one, in which he refers to himself as "the author" of the whole book, including the Introductory Dialogue; and there is conclusive internal evidence

1 Life of Scott, I, 279.

2 Johnston is mistaken in stating that not one of Scott's flve pieces in Tales of Wonder is in the A pology - a mistake probably due to the change in title. Scott at first called his translation of Bürger's "Der Wilde Jäger," " The Chase," and under this title published it in 1796, and printed it in the Apology in 1799; but he subsequently changed the title to " The Wild Huntsman," as it appears in Tales of Wonder. 
that this author was not M. G. Lewis. ${ }^{1}$ The verse and diction, except where he is specifically parodied, are utterly unlike his. So are the Augustan personifications and abstractions, the Latin quotations at the head of the poems, and the profuse classical allusions with which "The Mud-King" is annotated. Two of the pieces, moreover, are burlesque imitations of Lewis' own ballads in Tales of Wonder, and are dedicated to him by name; and "The Mud-King; or Smedley's Ghost," which closes the volume, is not only said to be written in imitation of "The Fisherman" (one of Lewis' translations from Goethe in Tales of Wonder), but it is a satire on Lewis himself. Even if it could be supposed that he would travesty his cherished goblin ballads in this fashion (and he did parody his Alonzo because someone else had done so), he would hardly have held himself up to ridicule, in the last one, as a Dunce poet, and brother bard to Smedley, with the allusion emphasized by an explanatory footnote.

What Professor Morley did with the two parodies in Tales of Terror that mention Lewis by name is not less mystifying than what he did with the title-pages of his source books. These parodies, "Grim, King of Ghosts," and "The Wolf-King" (a "gothicized" version of Red-Riding-Hood), are particularly hideous and successful imitations of Lewis at his very worst. Now, although Morley printed all the other poems in Tales of Terror with titles and notes just as they stand in the original, he omitted from the title of "Grim, King of Ghosts" the statement there printed, that it was written in imitation of "The Cloud-King" (by Lewis) and "dedicated [of course] to M. G. Lewis, Esq."; and he took no notice of the other parody that is dedicated to Lewis, beyond mentioning in his Introduction that four missing leaves compelled its omission. This omitted Tale is "The Wolf-King," the first page of which, at least, containing the title, the dedication, and the first stanza, must have stood intact in the volume he printed from, because he completed the preceding ballad from the reverse side of the leaf.

Another point, which so far seems to have escaped notice, is Scott's reference to Lewis' Tales of Wonder in his Essay on Imitations of the Ancient Ballad. "A very clever parody," he says, "was made

1 Some of this was pointed out by H. B. C. in Notes and Queries (3d Ser., X, 508) as long ago as 1866. 
on the style and person of the author, and the world laughed as willingly as if it had never applauded." As we have no knowledge of any other contemporary parody answering to this description, and as Tales of Terror followed hard upon the first edition of Tales of Wonder, it seems almost certain that Scott was referring to that work. It is possible, however, that, writing in 1830 , he may have had in mind "Fire and Ale," the clever parody of Lewis in Rejected Addresses, by James and Horace Smith, published in 1812.

Cambridge, Massachusetts

\section{Elizabeth Church}

